University of Nebraska - Lincoln

DigitalCommons@University of Nebraska - Lincoln

$7-27-2020$

\title{
Feeder Cattle Future Price Spreads: Opportunities to Hedge?
}

Elliott James Dennis

University of Nebraska - Lincoln, elliott.dennis@unl.edu

Follow this and additional works at: https://digitalcommons.unl.edu/ageconfarmmgmt

Part of the Agribusiness Commons, Agricultural Economics Commons, Beef Science Commons, Entrepreneurial and Small Business Operations Commons, Management Information Systems Commons, Other Business Commons, and the Other Economics Commons

Dennis, Elliott James, "Feeder Cattle Future Price Spreads: Opportunities to Hedge?" (2020). Extension Farm and Ranch Management. 44.

https://digitalcommons.unl.edu/ageconfarmmgmt/44

This News Article is brought to you for free and open access by the Agricultural Economics Department at DigitalCommons@University of Nebraska - Lincoln. It has been accepted for inclusion in Extension Farm and Ranch Management by an authorized administrator of DigitalCommons@University of Nebraska - Lincoln. 


\title{
Feeder Cattle Future Price Spreads: Opportunities to Hedge?
}

\author{
By Elliott Dennis
}

July 27, 2020

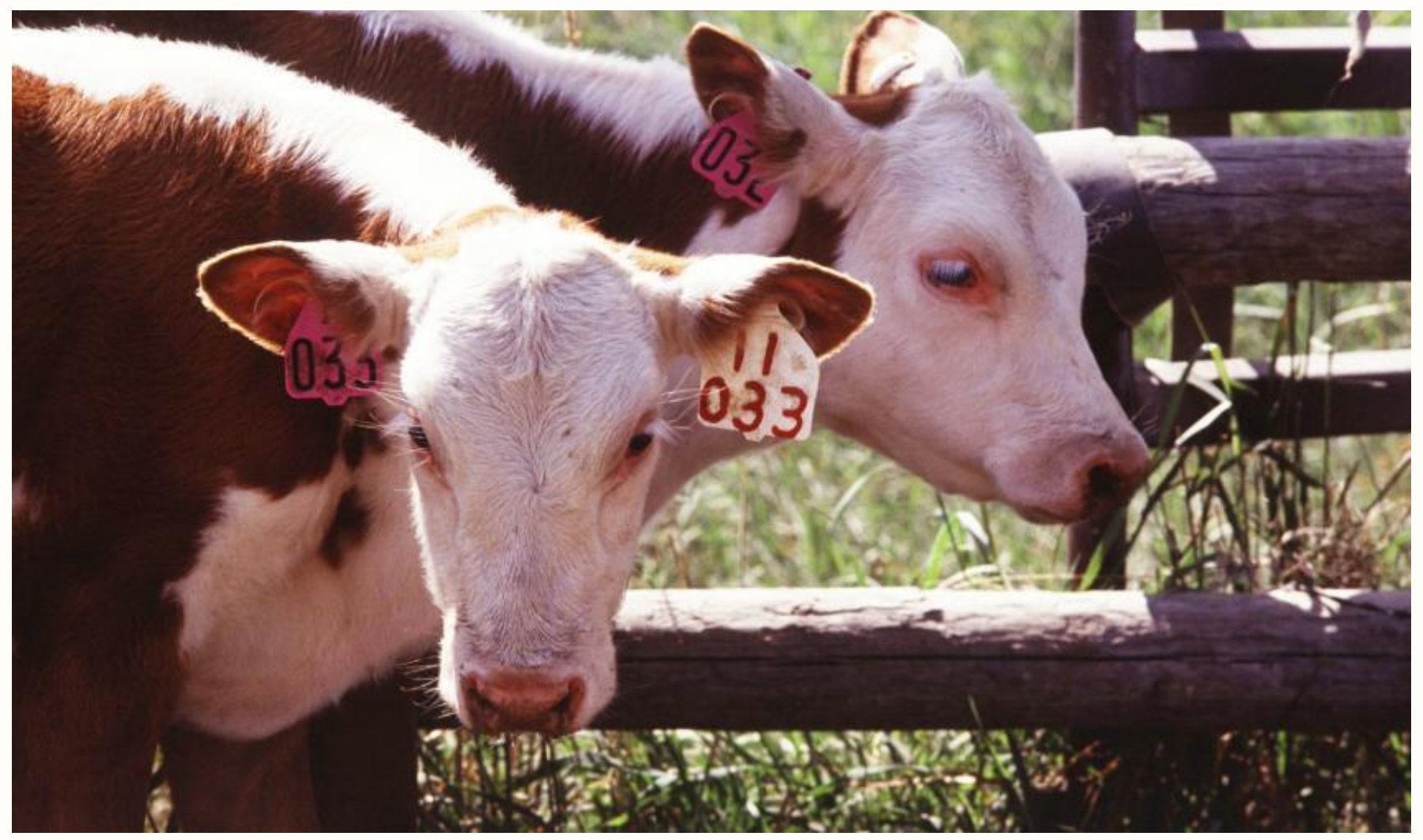

This article was originally published by In The Cattle Markets on July 2O, 2020. 
Feeder cattle future price spreads across all months have recovered to near pre-COVID-19 levels as quarantine restrictions and packing plant capacity issues have been mostly sorted out. For example, for the week of July 17, 2010, prices reached levels not seen since the beginning of March 2020. Pasture and corn progress are two factors that have the potential to push prices lower in the next coming months. Given current market conditions, producers have some options to lock in a margin.

\section{Pasture Conditions}

One the primary factors to continue to watch are declining pasture conditions. The weekly US range and pasture conditions rated "poor" and "very poor" has continued to rise since late May and early June. As of the middle of July, pasture conditions were $15 \%$ worse than the five-year average and $20 \%$ worse than 2019. Declining pasture conditions are largely the result of a drought progressing from the Southwest into the Great Plains. These conditions are largely consistent with the La Nina weather pattern. Pasture conditions are worse in Texas, Colorado, and New Mexico whereas most of the Southern and Western Cornbelt states have pasture conditions in "poor" and "very-poor" below 10\%. If pasture conditions deteriorate it could force producers to make earlier marketing decisions on weaned calves. Given the operations access to pasture and feed, cow-calf operations may need to choose between selling weaned calves in the fall or potentially wintering them till January.

\section{Corn Progress}

Corn futures generally begin their July runup in the beginning to middle of July often referred to as the "weather premium" (see Li, Hayes and Jacobs 2017). Although this year, the runup happened in the first few weeks of July as crop progress was behind and there was growing concerns that corn yield would be lower than expected. For example, for the week ending July $12^{\text {th }}, 29 \%$ of corn was silking and $3 \%$ was in the dough phase for the 18 reporting states. These were well below the five-year average of $54 \%$ and $7 \%$, respectively. Fast forward one week which received additional moisture and moderating temperature and silking increased to 59\% and dough to 9\%. Add this to the corn in "Good" or "Excellent" condition at 
69\% compared to 57\% a year ago and combined there appears little reason to believe that corn yields are currently affected by the La Nina weather conditions.

\section{Opportunities to Price Feeder Cattle Today}

Given the current pasture and corn conditions, are there opportunities to price feeder cattle? one way to look at this decision is to look at the futures offer curve. Well it is true that different livestock futures contracts months can be more disconnected than grain futures contracts, the offer curve can still provide useful future pricing signals. In figure 1 I plot the observed July futures price for each CME futures contract for each year between 2011-2019 excluding 2015 and 2016. The shape around each CME futures contract are density curve estimations and visually shows how (dis)similar prices are across years.

Futures contracts that are farther in the distance have more variable prices, as expected, given that there is more time before cattle are marketed and thus a higher probability supply and demand conditions will change to impact price.

The red dot represents the median price across all years, the black x's are the July prices for the given CME futures contract in different years, and the blue stars are the current July 2020 price levels. As of July 20, 2020, futures prices across all CME contracts were at or near median levels suggesting producers looking to protect some margin have similar opportunities that they have had, on average, between 2011-2019. October 2020, November 2020, April 2020, and May 2020 feeder futures contracts are all priced very competitively. Every futures contract is currently priced within $\$ 1.50$ of the median prices. In other words, currently the market is offering producers the option to lock in an average margin. Given the COVID-19 market volatility this is quite remarkable.

\section{La Nina Price Improvements}

Given we are in a year typified by La Nina weather patterns, historical price analysis in other years that also experienced La Nina weather conditions can provide some indication of where prices are likely to end up at contract expiration. Economic theory would suggest that as pasture conditions worsen cattle 
are forced to enter feedlots earlier, increasing the supply of feeder cattle effectively lowering feeder cattle price in nearby months but raising them in deferred months. Under these assumptions there would be a strong signal to either price today before cattle begin to leave grass or to wait till most cattle are placed in the fall. The data would suggest likewise.

To validate this economic theory, I compare how the current July 2020 prices, where the severity of the La Nina pattern is unknown, to other marketing years where La Nina occurred. The National Oceanic and Atmospheric Administration (NOAA) categorizes the weather patterns of each year as either La Nina or El Nino and assigns the severity of the pattern as "Mild", "Moderate", or "Strong". From each severity category I chose two years and then calculate the percent change in prices from July to contract expiration for the FCF contract. Figure 2 plots these results. The results suggest that prices in July for the FCF futures contract have tended to strengthen in La Nina years regardless of the severity. The only exception is the FCF96 contract. Price improvements were minimal between July and September. Approximately $3 / 4$ of all the price improvement occurred between September and the middle of October. There was an average of $6 \%$ increase over July prices for the FCF contract. In other words, for FCF21 where the severity of La Nina is unknown, a potential expected price level could be approximately $\$ 150$ (. If producers desire to wait for potential price improvements in the market, the preceding figure would suggest pricing now or waiting till September. Pricing now would eliminate some downward price risk due to potential increasing government quarantine restrictions whereas waiting till September would offer insights into observed feedlot placement decision. 
Department of Agricultural Economics | Extension | University of Nebraska-Lincoln Farm and Ranch Management

DOI: $10.13014 /$ frm00019

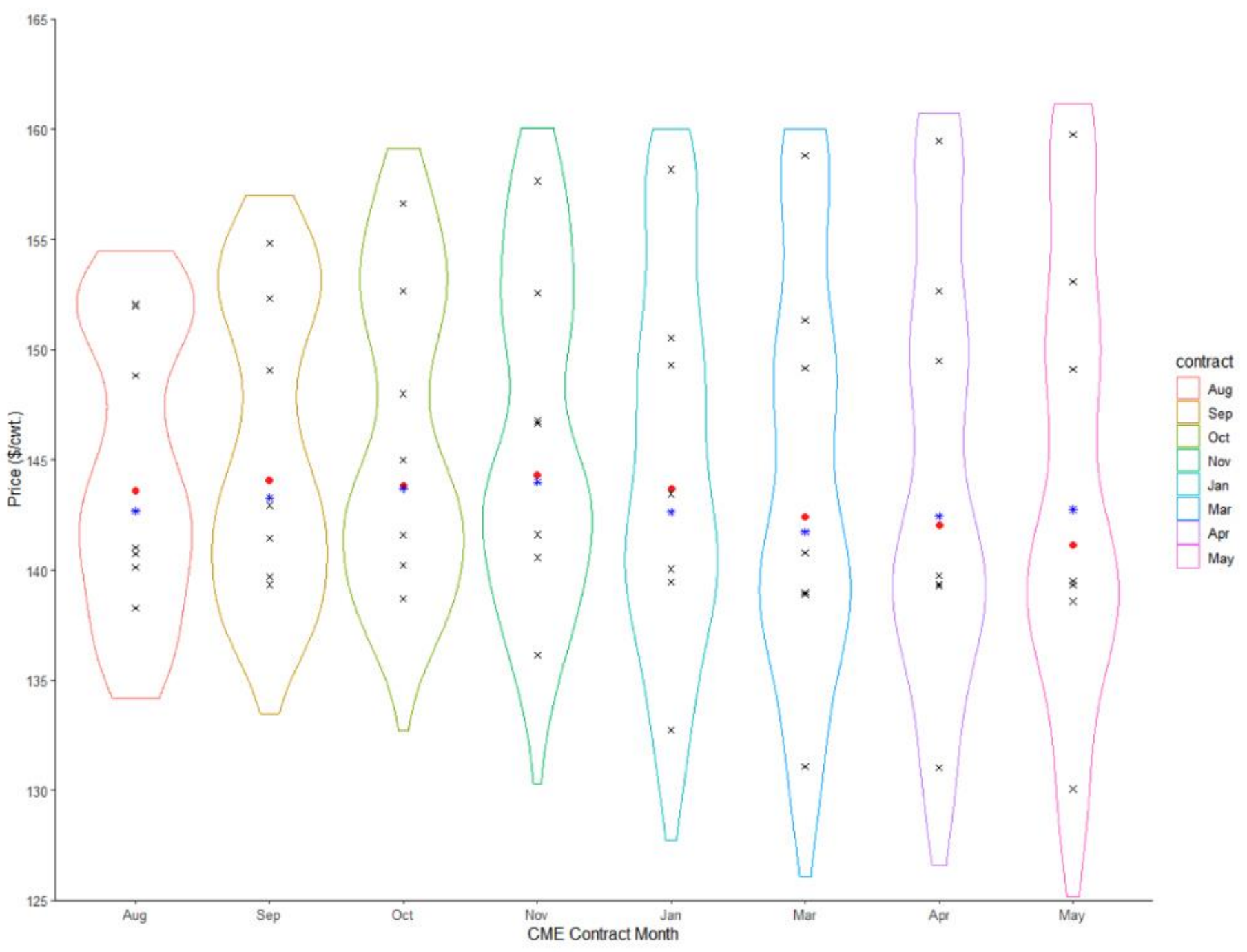

Figure 1. Density Curves and Points for July prices for Various CME Contracts

Notes: Years used include 2011-2019 excluding 2014 and 2015. Inclusion of these years greatly skews the figures and thus were excluded. Data were collected from LMIC (2020). 
Department of Agricultural Economics | Extension | University of Nebraska-Lincoln Farm and Ranch Management

DOI: $10.13014 /$ frm00019

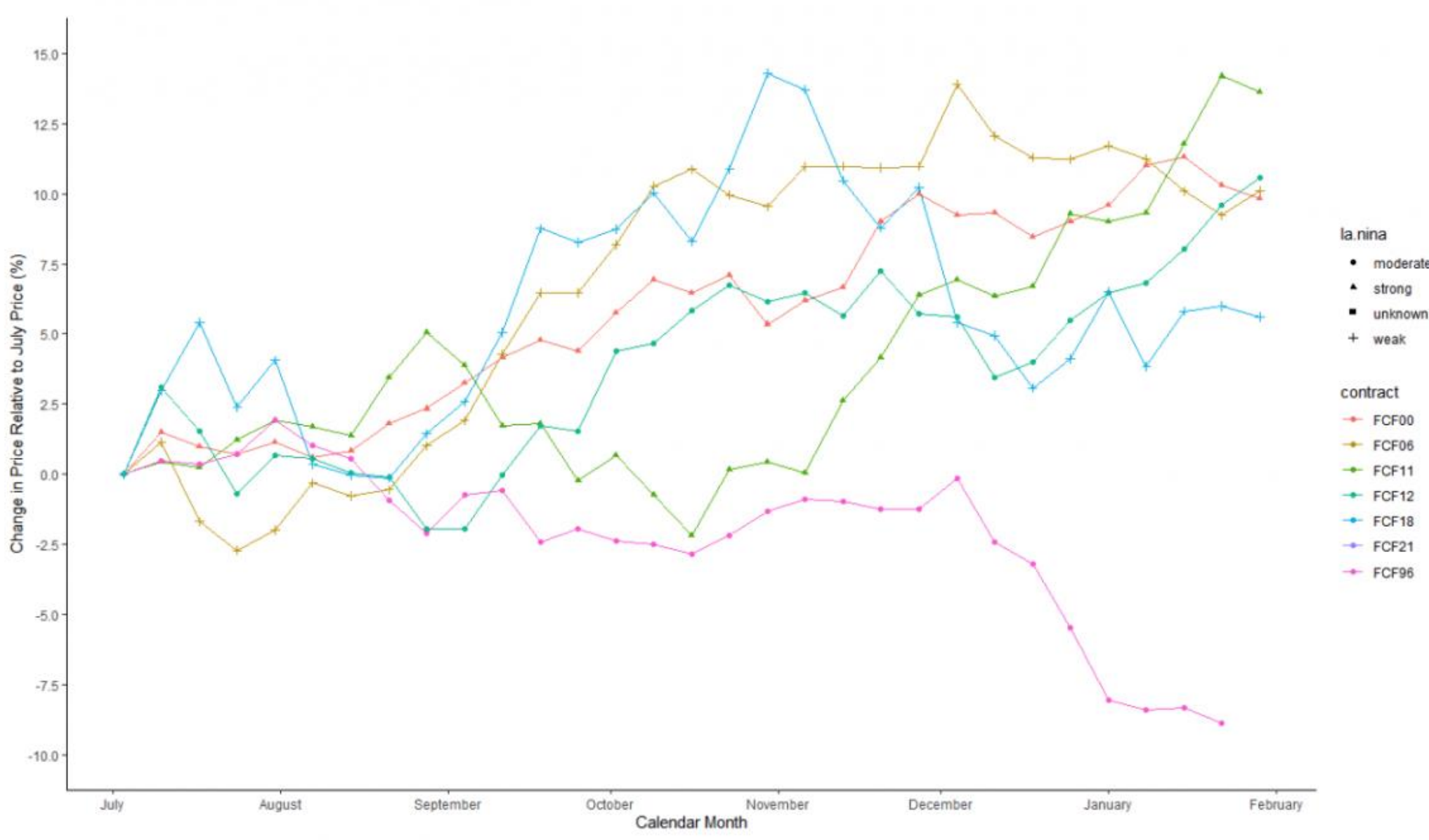

Figure 2. Percent Change in July Prices for the January Feeder Cattle Contract

Notes: Price data was collected from LMIC (2020). Weather condition classifications were gathered from NOAA (2020). 